\title{
Local Governance in Khyber Pakhtunkhwa: Regimes Response and People Perceptions
}

\author{
* Dr. Bakhtiar Khan, Assistant Professor (Corresponding Author) \\ ** Dr. Saeed Ahmad, Associate Professor \\ *** Dr. Arif Khan, Assistant Professor
}

\begin{abstract}
The passage of the 18th Amendment to Constitution of 1973 of Pakistan is a major constitutional development to strengthen local system of government in Pakistan. The amendment constituted one of the most dramatic devolution of power since drafting of 1973 Constitution. The increased authority accorded to provincial governments has enhanced their ability to retain control of their revenue; however, most taxes will continue to be redistributed by the center. The amendment authorizes the provinces to establish the local government system. This paper focuses on the failure of various provincial governments to conduct periodic local body's elections and to implement the system. The study also focuses on the political leadership insincerity in their commitment to devolution of power to the local representatives. The study finds out that contrary to non-elected institutions elected institutions are to greater extent reluctant to empower local representatives. The study also finds out that despite lack of political will, unsound financial conditions remained a major obstacle in deepening the roots of these institutions. These elected representatives at federal and provincial level half-heartedly supporting this system as they think of the later will reduce their influence and will decrease their power base.
\end{abstract}

Keywords: Local Government, Awami National Party, Pakistan Tekhrik-i-Insaf

Introduction

The system of local governance remained a blistering subject and is debated in the much of the academic discussion throughout the world. Throughout the developed world this system yields useful results at the lower echelons of governance and solved problems at the gross root level. Democracy is recognized as the most suitable system for the welfare of the common man. Democratic style of governance enables citizens to choose representative of their choice among the alternative candidates. It also provides opportunity to peoples to contest elections for the federal and provincial legislature to express their will and claim their rights. But the concept of local governance or self-governance terms often used interchangeably by writers and academicians for democratic system at gross root level. Pakistan a developing country inherited the system from British but could not practice it due numerous reasons. General Ayub Khan's system of basic democracies 1959 was the first concrete manifestation of this system as he used it to strengthen his position and prolong his rule. With the doom of Ayub his system of basic democracies also died. Then General Zia Ul Haq the third military ruler under the local government ordinance 1979 and General Pervez Musharraf under his local government ordinance 2001 held elections and introduced local government systems.

Local governance enables the citizens to participate in decision-making process at the grassroots level. Unlike the military rulers a number of elected governments were found reluctant to adopt the system of local institutions. The existing laws were not implemented in true spirit and resultantly local elections could not be held regularly. The first popularly elected government of Pakistan People's Party in the country under Zulfikar Ali Bhutto introduced this system with the name People's Local Government. Nevertheless, it remained restricted to document and unexecuted (Khan, 2016).

Like Bhutto all the succeeding elected governments followed him and showed little interest to strengthen this participatory institution so that the common citizens of the country could solve their

\footnotetext{
* Department of Political Science, University of Buner (Swari). Email: bakhtiar@ ubuner.edu.pk

** HED, Government Degree College Bakhshali, Mardan.

*** Department of Political Science, University of Buner (Swari).
} 
problems locally. The government of Awami National Party under Chief Minister Amir Khaider Khan was expected to hold regular and timely elections of the local government institutions in the province but delayed it unexpectedly. Later- on PTI likely to hold polls of the local body institutions at its stipulated time also failed in so doing. This delaying tactics caused irreparable damage to the system of local government

\section{Understanding Local Governance}

Being autonomous institutions, local bodies work and function as a nursery for democracy and political socialization and ensuring services to the people at their doorstep. Unfortunately local government system is not up to the mark in Pakistan in general and Khyber Pakhtunkhwa in particular. When seen in the comparative international context, this system has not worked very well and now to know the importance of this institution it is pertinent before everything to understand about this institution. The meaning and definition will comprehend us properly to proceed into the enquiry of local governance further. National and provincial legislatures are making laws in the interests of the whole nation or a particular province respectively. This representative as it has been read and understood often has to look back to their respective constituencies. In simple words it is difficult to reach and feeds the demands of each and every electorate by these representatives. For the purpose to meet these challenges the world is practicing this system of local governance since long time. In this sense local means restricted or limited to a place, locality or district and governance means machinery that exercise state authority and program and functions. From the above two separate meanings we can understand local government means a government in miniature. To comprehend the concept further this explanation enriches our thoughts to a greater extent. Local government is that form of government which serves only a smaller area and exercise the delegated power.

From here we will proceed a step further to find out whether there is some inherent deficiencies in the system due to which it is not acknowledged in Pakistan or there were lack of political will to allow this form of government and gain the anticipated results. Answers to these thought provoking questions need research. If most of the countries particularly Europe, US have this system working smoothly and efficiently then there is no fault in the system but something inherent weakness lies in Pakistan's environment. That is as Anas Malik mentioned in his book political survival in Pakistan that security priorities have undermined development in Pakistan, in generating accountable institutions and in allocating resources to education, health care and other human development (Malik, 2011: 31).

Many researchers have pointed out a number of reasons for the failure or not accommodation of the system to this land and its people. For instance various reasons have been put forwarded like: no democratic environment, firm grip of bureaucrats over political institutions, poor electoral system, role of politicians and political parties, functional problems and political instability. These are some worth considering lacunas that greatly contributed in the proper and efficient functioning of this institution in Pakistan. But apart from these apparent reasons there seems to have more important things that contributed to this dilemma. This piece of research tries to pin point those vital areas that if focused by the authorities can contribute in promoting this system.

\section{Methods and Data}

The study is broadly based on historical and descriptive evidences. Both primary and secondary sources are utilized for data collection. Among secondary sources books specifically focused on local government in Pakistan are of prime importance for this study. These manuscripts guide and provide foundations to this study. Research articles from reputed journals have been taken into account to support the current study so as to enrich the understanding not only of the author but for the future researchers interested in the area. Leading newspapers, periodical and historical documents were included to further strengthen the author's argument. Empirical data collected through interviews with the ex- officials of local bodies' institutions of the different union councils.

\section{Dearth of Periodic local Polls in KPK}

It is known that local government system is the legacy of colonial master to Pakistan through the act of 1935. The initial hurdles faced the country were in no way favorable to divert the attentions of the founding leaders as they were overwhelmed with numerous other problems. Among those teething troubles were: framing of constitution for the country, settlement of millions of refugees, financial as 
well as threat from the mighty and hostile neighbor. This was the beginning setbacks that weakened the roots of local self-government in Pakistan to get deeper its roots. A decade later Ayub introduced the system for the purpose to legalize his rule and not to promote the system. Elections for basic democrats were conducted that later on served as an electoral college for his presidential election in 1965. Succeeding regimes weather military or civilian turned deaf ear to the periodic elections of the local bodies in the country particularly in the KPK province. By branding the local government as military legacy, the elected governments of the province simply ignored it. No periodic elections were held even if an elected government started to take the initiative; it hesitated to obvious political reasons. The recent outstanding manifestation is delaying the elections of local government in KPK was the ANP and PTI governments.

Now the constitution of 1973 after incorporating the historic eighteen constitutional amendment provides certain important provisions for the devolution of authority to the local representative through the implementation of the Local Government: first among these provision are the State shall support Local bodies institutions comprised of chosen agents of the locality concerned and enough representation will be given to farmers, working class and females in such institutions. The aim would be the promotion of social justice and abolition of societal ills. Secondly it is the responsibility of the state to make possible the decentralization of government administration so as to make necessary adjustment in its rules and regulations to fulfill the legal demands and necessities of the masses. For decentralizing not only political but administrative and financial responsibility as well all the four federating units shall, by law, establish the system of local governance (Khaliq, 2012).

The 18th amendment to the constitution provides that the responsibility for founding the structure of local government rests with the province concerned and also gave the responsibility for administering local government elections to ECP. During Pervez Musharraf tenure, when the term of local governments completed in 2010, these local elected assemblies were dissolved. Except Baluchistan, all other provinces avoided the necessary legislation and deferred the elections. The delay was seen as the lack of will on the part of political leadership who were unwilling to transfer power from provincial level to local representatives. During a hearing of the "Baluchistan Law and Order" case in April 2012, the highest Court of Pakistan acknowledged that there is a vast gap between the government and common man. At that point of time, Chief Justice of Pakistan asked for details explanation from all the provinces. The provinces had to explain as to why the local elections could not been held -in time and also to inform the Court of their planned election schedules by May 2012. The provinces made use of delaying tactics and did not pass any legislation for elections. On the other hand the court continued to put pressure and on 2 July 2013 the court ordered the conduction of local government elections at their earliest by all provinces. It was the provincial government of Baluchistan which replied positively and the local bodies elections were then held on December, 7 2013. All the remaining 3 provinces i.e., KP, Punjab and Sindh, enacted essential legislation and the Supreme Court ruled in March 2014 that elections should be held by November 2014.

However, delimitation conducted by Punjab and Sindh was invalidated by the high courts and the electoral process was postponed. This was followed by the Supreme Court judgment that the authority to define constituency boundaries should be transferred to the ECP before the process resumes. However, since the delimitation conducted by the KP government was not dismissed by the high courts, on 4 April 2015 the ECP announced the KP election schedule for 30 May 2015. These developments were unfolding in a stressed political milieu, challenging authenticity of the 2013 general elections. Large scale demonstrations started against the alleged rigging in the elections of the 2013. Resultantly, General Elections 2013 Inquiry Commission was formed which was investigating PTI's accusations of the organized electoral fraud (Report, July 2015).

\section{Awami National Party Government and Local Elections}

In this connection the province of Khyber Pakhtunkhwa, passed Local Government bill in May, 2012 and was published as an Act of the Provincial Legislature of the Khyber Pakhtunkhwa after getting approval of the governor (LG Act, 2012). The Province of the Khyber Pakhtunkhwa to constitute, regulate and consolidate the Local Councils as well as relevant laws to Local Councils institutions and other related matters. According to the preamble of the Act local governments institutions be established which will composed of locally elected representatives of people. It also says that special representation be given to peasants, workers, women and minorities .Article 140A (1) of 1973 
constitution of Pakistan provides for establishment of a local Government system and decentralization of political, administrative and financial authority and responsibility to the local Governments through its representatives. To achieve this purpose it is indispensable to revisit and make stronger laws relevant to this Institution (LG Act, 2012).

It was also provided in the Act that the principle of universal suffrage viz-a-viz secret voting must be observed for the elections of candidates in these elections. The provincial government was authorized to make arrangements as required for reducing or increasing the size of constituency as necessary for purposes of election. Multi-members shall contests elections a Union Council. The Act says that one electorate from the constituency is allowed to choose among the members inside the electoral area by casting single vote. Under the said act the provincial government of ANP in Khyber Pakhtunkhwa had to conduct local bodies' elections but it neglected its responsibility. Though the ANP government passed Local Government Act 2012, nevertheless, failed to implement it by turning a deaf ear to hold the long awaited elections in the province (Khan, 2016).

\section{Local Government Act 2013 and PTI Government}

When the result of the general elections 2013 were announced, Pakistan Tehreek-e-Insaf (PTI) secured majority of seats in Khyber Pakhtunkhwa province and was successful to establish a coalition government in KPK province. In fact, PTI contested the elections by raising the slogan of "Change". Majority of Pashtuns considered PTI as their messiah and voted it into power. It surprised and ousted the traditional politicians who had strong base in the province. Resultantly, being dominant partner in the coalition, Pakistan Tehreek-e-Insaf appointed Pervez Khattak as the Chief Minister. The ruling coalition held 80 seats out of which 56 were from PTI and 26 seats held by Jamaat-e-Islami (JI), Qaumi Watan Party (QWP) and Awami Jamhuri Ittehad Pakistan (AJIP). The opposition which consists of Jamiat Ulema-e-Islam F (JUIF), Pakistan Muslim League N (PML-N), Awami National Party (ANP) and Pakistan People's Party (PPP) secured 42 provincial seats. A key point of the party agenda is devolution of power and re-establishment of local governance, thus after the general elections, the governing coalition debated decentralization. Unfortunately, all issues were not resolved by the time of the local elections as the rules of business, which guide operation of local councils, was still under consideration. A number of senior politicians raised their reservations and informed DRI that they were not clear what will be the powers limit of local councils and also about their relationship with the existing district governance under civil servants. There was a no up-to-date population statistics in the country, as the last census took place in 1998. Population composition was controversial especially given the implications of population shifts resulting from conflict in Afghanistan and the erstwhile Federally Administered Tribal Areas (FATA). The total estimated population of the province (for mid-year 2014) was $27,933,000$, with the majority $22,673,000$ living in rural areas and an estimated 5,260,000 living in urban areas. The 1998 census data indicated that 74 percent of the population considered Pashto to be their mother tongue, and less than 1 percent considered Urdu as such. The 1998 census claimed the male literacy rate to be 52 percent, dropping to 19 percent for women (LG Act, 2012).

However, the Pakistan Economic Survey 2012-1315 claimed the overall literacy rate in KP to be 52 percent, with male literacy at 72 percent and female literacy at 35 percent. Ongoing conflict in adjacent FATA and experience from the 2013 general elections indicated that there was a risk of violence in the KP local election campaign and that security issues would threaten the electoral process. The 2013 EU report concluded that, "Attacks on the campaigns of political platforms, contestants, supporters of party, party premises and electoral locations augmented considerably as the election date approached and that, "Baluchistan and KP suffered much due these countless assaults." KP government under Pakistan Tehreek-e-Insaf (PTI) conducted with a gap of ten years these local government elections on May 30, 2015 in the province under LGA, 2013 (LG Act, 2012).

\section{Delimitations of Local Government Constituencies}

Article 140A of 1973 constitution empowers Election Commission of Pakistan to hold elections of the local governments. Supreme Court of Pakistan in its decision Dated 20-03-2014 in civil Appeal No. 38 to 45/2014 and C.P. No. 297 of 2014, directed the Federal Government to make needed arrangement to authorize the Election Commission of Pakistan to carry out the delimitations of Constituencies. As PTI led provincial government failed to conduct local bodies' elections within 90 days as promised while the party had no intentions to do so. Being the opposition party in the 
provincial government of Punjab, PTI focused its energies towards the legislations proposed by the Punjab Assembly signifying the future local elections of lower level must have no political interferences (Report, July 2015).

Surprisingly, in KPK where it holds power, with the consultation of its coalition partner Jamat-e-Islami has proposed a draft bill on the pattern of Punjab. Ijaz Ahmad Chaudhry (PTI Punjab President) has said, "We will not let Punjab government pass this 'objectionable' bill, and will resist holding elections on non-party basis." Mian Shahid Latif member of national assembly from Pakistan Muslim League-Nawaz (PML-N) responded to Ijaz Ahmad Chaudhry statement and said that PTI should focused of its activities in the KP and don not go along with us on the issue. Promptly, Ijaz Chaudhry has denied by saying that in KPK the party intending to hold elections on a three-tier formula with the introduction of a new concept of village council and for the first time. The party coalition partner, JI was in favor of no political involvement in the elections at the level of union council in the province. Therefore, there are serious differences on the issue and the ruling party still wanted full participation of political parties in the poll at each and every level in KPK.

The KPK minister responsible for local government told The Express Tribune that the decision to hold provincial elections at union council level on non-political basis was taken after consulting coalition partners. The Apex Court of Pakistan has called written explanation from the central as well as all the provincial governments as why the local bodies' polls had not been conducted by the deadline of September. The Punjab province has given December 4 as date of elections. However, the government of KPK has to explain its position that why these elections were delayed and the government violated several constitutional provisions and has turn down repetitive reminders from the Supreme Court (Report, July 2015).

\section{Government Attitude and People Perceptions}

Last local bodies elections were held in Khyber Pakhtunkhwa western province of Pakistanin May 2015. More than eight thousand candidates participated in the scheduled elections. These candidates contested 41,762 seats on district, town, and neighborhood and village councils. These were the first local elections in the province for ten years. These elections like previous elections were conducted on non-party basis but the contestants to a greater extent had political affiliations. They had the support of one or the other political form. Most important of the said elections was that the party in power although, apparently showed enthusiasm but most likely dislike to transfer power to the lower level. The first example was according to Muhammad Zahid Ex-Nazim Village Council Jungara Union Council Gujrat Mardan who was the candidate of the Awami National Party the existing government delayed oath taking ceremony for four months (Zahid, April 18, 2020).

Local government institutions in the country and especially in the province of KPK were treated unjustly. This uneven treatment from power elites shaken roots of the system because fund were distributed to those had strong party members. Even they had got more than opposition party candidate (Islam, April 18, 2020). The miserable state of local bodies institutions in the province is that its four years expired on August 28, 2019 still government response is lazy. All the responsibility of official dealings has been shouldered by village secretaries and naib qasids. They are responsible for the routine business of local institutions in their respective union councils (Khan, April 17, 2020). They are looking after normal public dealings like signing death certificates and sanitations. So in the absence of proper setup the system is worth losing its credibility among the common peoples. Now the election commission is duty bound to announce to take active step and announce new dates for the new elections. Once again elections for the local bodies confronted with unwillingness, personal interests and political blame game of the political parties. The existing PTI government using delaying practices of restoring the system (Khan, April 16, 2020).

Respective provincial election commissioners were directed by the Election Commission of Pakistan (ECP) on Friday to complete preparation of electoral lists at the earliest in view of the local government elections to be held in the four provinces of the country. Though it is too early to speculate as to when the local bodies' elections will be conducted in the four provinces, the Election Commission wants the related job to be done as early as possible. Indeed, there are so many issues to be addressed by respective provincial governments, including enactment, amendments of laws etc. but the Election Commission is keen to least delay in the electoral exercise," a senior official at the Election Commission said (The News, April, 18 2020). 
According to a statement issued by the Election Commission, the revised preliminary electoral lists will be published in November 2020. For public convenience, display centers and inspection centers will be established in every district. This will enable the individuals to check their names and details in the electoral lists. Under Section 27 of the Elections Act, 2017, registration of a voter can be made on temporary or permanent address. The Election Commission will also launch voters' awareness campaign next month. It is pertinent that the total number of registered voters, both males and females is around 10 crore and 90 lakh, and according to an estimate, the number is expected to 11 crore and 30 lakh.(The News, April, 18 2020).

\section{Findings and Suggestions}

The study finds out that contrary to non-elected institutions elected institutions are to greater extent reluctant to empower local representatives. The study also finds out that despite lack of political will, unsound financial conditions remained a major obstacle in deepening the roots of these institutions. The political unstable conditions rivalry among the parties, at the same time to defame and destabilize the incumbent in office greatly contributed enormously. These elected representatives at federal and provincial level half-heartedly supporting this system as they think of the later will reduce their influence and will decrease their power base. The study suggests that all stockholders should think positively and concentrate on the system to get roots in the country. With this step not only people would get their due rights but also they would be socialized in the system and in future slowly and gradually mature leadership will emerged in the country.

\section{Conclusion}

The history of local government in the country to date, reveals that despite enthusiasm manifested by the elected and military rulers in the past, there has been marginal alteration in the real position of the government hold and hence in the degree of independence enjoyed by local government. The power elites in particular had overlooked that in the absence of strong and stable gross root level elected institutions, a superstructure can neither be created nor made to operate successfully. The major concern of party power struggle in general has been to manipulate local bodies for the promotion of party interests. The problem is further aggravated when two opposition parties are in power at the provincial and local level respectively. Thus party bickering not only delayed the scheduled elections for the local bodies but also brought the whole administration to a standstill when party considerations were taken to their extremes. Unless a political culture is developed, where there prevails awareness, tolerance and an environment of confidence to do things independently, there are very few chances that simply allowing of constitutional status will produce significant results. Therefore, resolving the pressing problems confronting the system itself there are little prospects for the stability, continuity and sustainability of the local government institutions in Pakistan.

\section{References}

Amirullah, Khan. (2016). Paradox of Local Democracy in Provinces: Case Study of Khyber Pakhtunkhwa Local Government act, 2013. JPUHS, Vol.29, No.1.

Anas, Malik.(2011). Political Survival in Pakistan. London: Routledge, p. 31.

Ayaz Ahmad, "Challenges To Local Bodies", The News, November 13, 2015.

Daily Express, May 30, 2015.

Democracy Reporting International. Khyber Pakhtunkhwa Local Government Elections Assessment. Report July, 2015.

Imran Adnan, "Local Governments: Punjab lagging behind in devolution of municipal services", Daily Express, October 19, 2015.

Interview of the author with Abid Khan, Ex-Nazim, village council-1. Union Council Gujrat, Mardan. On 18-04-2020.

Interview of the author with Asmat Khan, General Councilor, village council- 1 Union Council Gujrat, Mardan on 19-04-2020.

Interview of the author with Izzat Khan, General Councilor Union Council Bakhshali, Mardan on 1604-2020.

Interview of the author with Muhammad Zahid, Ex-Nazim, VC- ii. Union Council Gujrat, Mardan on 18-04-2020.

Interview of the author with Sajjad Khan, Ex-Nazim Union Council KattaKhat, Mardan on 17-042020 . 
Interview of the author with Ziaul Islam, Ex-Naib Nazim, Village Council- 1. Union Council Gujrat, Mardan on 18-04-2020.

Khalid Aziz, "Appraisal of Local Governance at the Federal, Provincial, and District Level in Khyber Pakhtunkhwa Province, Pakistan”, Criterion Quarterly, Vol. 11. No. 1, May 30, 2016. http://criterionquarterly.com/

Local Government Act- 2012.Khyber Pakhtunkhwa Act No. VIII of 2012 (May 2012) 10.

Local Government Act- 2012. Khyber Pakhtunkhwa. Act No. VIII of 2012 (May 2012)

Local Government Act, 2001 Khyber Pakhtunkhwa.

Muhammad, Khaliq.(2012).Local Government System in Khyber Pakhtunkhwa: A Historical Analysis.

Ordinance. No VIII of 2014.Published in the Gazatte of Pakistan, in extra ordinary part-1 dated the $14^{\text {th }}$ October, 2014.

Syed, Muhammad. Ali. (March, 2007). Ranking Local Government Performance in Pakistan through Scorecards. Research Report. South Asia Partnership-Pakistan, Lahore.

The Khyber Pakhtunkhwa local government act, 2012.Khyber Pakhtunkhwa act no. Viii of 2012. 